\title{
WESTERN SCREECH-OWL (MEGASCOPS KENNICOTTII CARDONENSIS) IN THE SIERRA LA ASAMBLEA, BAJA CALIFORNIA, MÉXICO
}

GORGONIO RUIZ-CAMPOS and GONZALO DE LEÓN-GIRÓN, Laboratorio de Vertebrados, Colección Ornitológica, Facultad de Ciencias, Universidad Autónoma de Baja California, Ensenada, Baja California, 22860, México; gruiz@uabc.edu.mx, gondro2@hotmail.com

PHILIP UNITT, San Diego Natural History Museum, P. O. Box 121390, San Diego, California 92112-1390; punitt@sdnhm.org

From 6 to 9 June 2016 Ruiz-Campos and León-Girón participated in a biological exploration of the Sierra La Asamblea, an isolated mountain range in the central desert of Baja California, lying about $25 \mathrm{~km}$ east of Laguna Chapala and about 65 $\mathrm{km}$ northwest of Bahía de los Angeles. Reaching a maximum elevation of $1661 \mathrm{~m}$ above sea level, the Sierra La Asamblea can be considered a sky island, having some plant species characteristic of transitional chaparral such as Rhus ovata (sugarbush), Juniperus californica (juniper), Ephedra californica (California ephedra), and Simmondsia chinensis (jojoba) as well as plants more typical of the lower surrounding desert such as Brahea armata (blue palm) and Prosopis glandulosa (honey mesquite). The plants of the Sierra Asamblea have been surveyed to substantial degree by Bullock et al. (2008), but our visit in June 2016 was the first by biologists focusing on birds

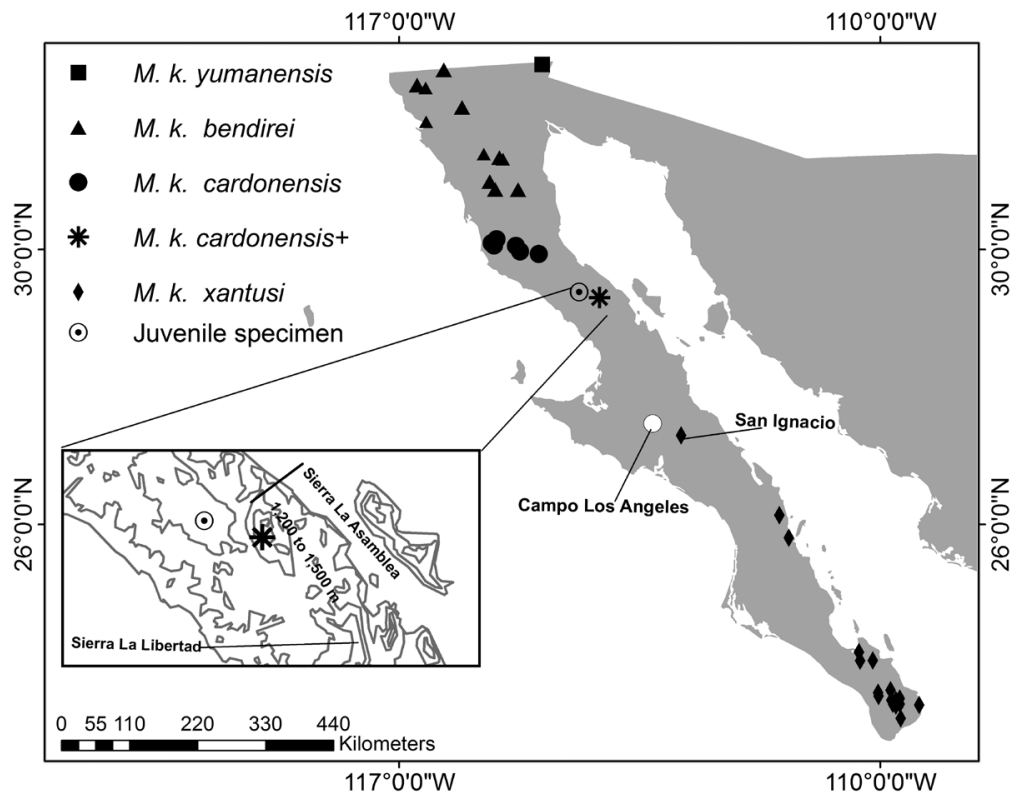

Figure 1. Distribution of specimens of the Western Screech-Owl on the peninsula of Baja California. 


\section{NOTES}
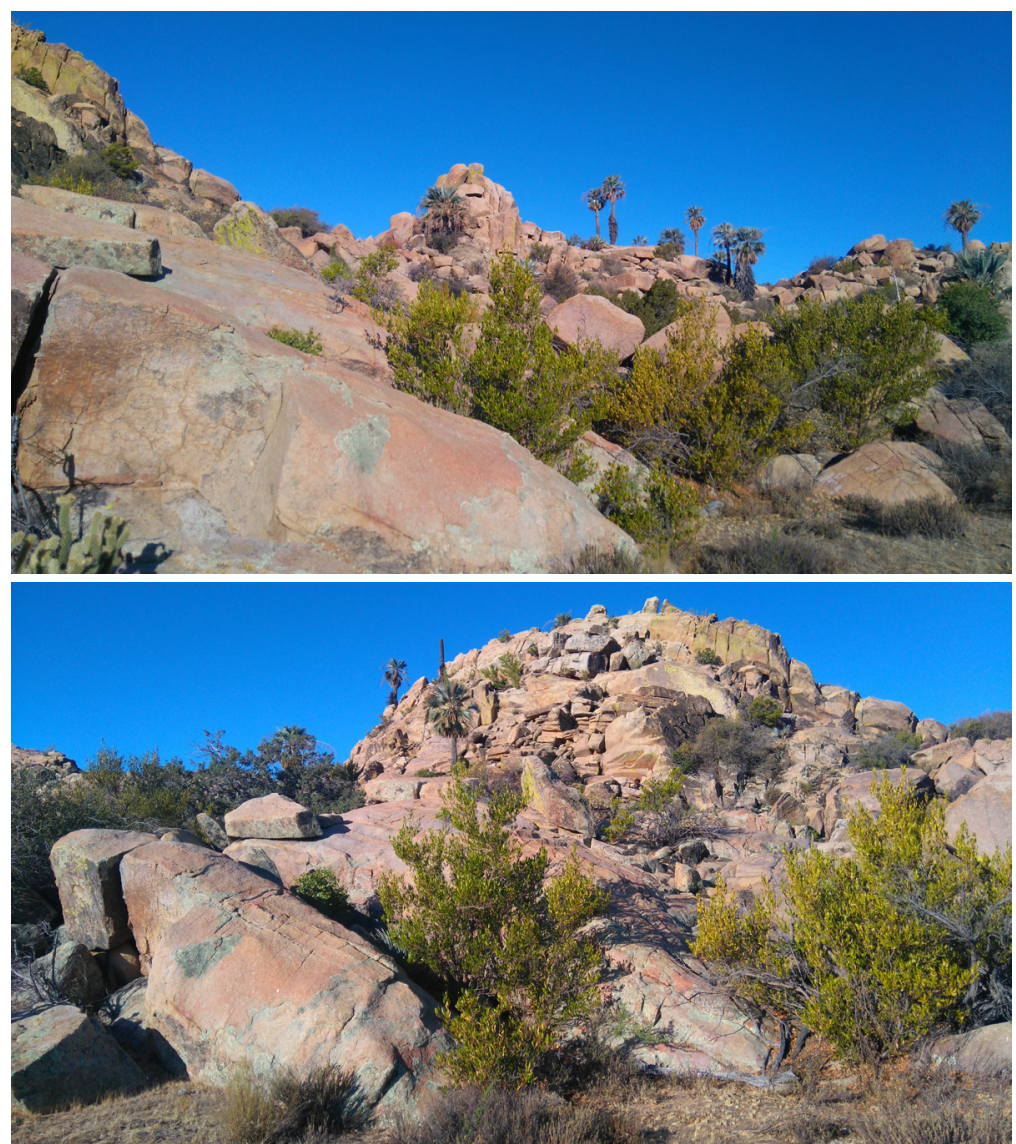

Figure 2. Transitional chaparral vegetation at the site of collection of the Western Screech-Owl at Los Llanitos, Sierra La Asamblea, Baja California.

Photos by Gorgonio Ruiz-Campos

(Erickson et al. 2001, 2013). We did not reach the highest elevations of the Sierra La Asamblea, which support stands of Pinus monophylla (single-leaf pinyon) and Adenostoma fasciculatum (chamise). Therefore our survey of these mountains can be considered only preliminary.

By means of a single mist net placed on the plateau of Los Llanitos $\left(29.30046^{\circ}\right.$ $\mathrm{N}, 114.08583^{\circ} \mathrm{W}$, elevation $\left.1219 \mathrm{~m}\right)$, we collected 10 specimens of nine species. This site lies about $7.4 \mathrm{~km}$ south of the highest point of the Sierra La Asamblea (Figures 1 and 2). The birds we observed and collected are all previously known from lower elevations in central Baja California. Among the specimens is one Western Screech-Owl (Megascops kennicottii), a male captured on 9 June 2016, deposited in the bird collection of the Universidad Autónoma de Baja California (UABC 2086) 


\section{NOTES}

at Ensenada, Baja California, Mexico. We also heard two individuals in the same area on 7 June. The Western Screech-Owl is little known in central Baja California: through www.vertnet.org we find only three study skins collected in the $800 \mathrm{~km}$ between San Agustín $\left(29.95^{\circ} \mathrm{N}\right)$ and La Paz $\left(24.15^{\circ} \mathrm{N}\right)$, and only four reports via www.ebird.org in the same region.

Of the nine subspecies of the Western Screech-Owl recognized by Cannings et al. (2017), four occur in the Baja California peninsula: $M$. $k$. yumanensis in the lower Colorado River basin, M. $k$. bendirei in the region of Mediterranean climate in the northwest of the peninsula, $M$. $k$. cardonensis in the central desert, and $M$. $k$. xantusi from Campo Los Angeles in the Desierto de Vizcaíno $\left(27.47^{\circ} \mathrm{N}, 113.30^{\circ} \mathrm{W}\right)$ and San Ignacio south to the cape region (Miller and Miller 1951, Marshall 1967). Subspecies cardonensis is still known principally from the nine specimens in the San Diego Natural History Museum (SDNHM), collected 10-16 km east of El Rosario, on which Huey (1926) based the original description. In their map of the Western Screech-Owl's distribution in Mexico, Howell and Webb (1995) suggested a gap between these two last subspecies in the central peninsula, a gap in which the Sierra La Asamblea lies. The only specimen collected previously in this gap, LACM 73852 (Natural History Museum of Los Angeles County), from Laguna Chapala, 22 July 1939, is a molting juvenile in which the characters of the subspecies are not discernible. Therefore we investigated what subspecies UABC 2086 represents.

The subspecies of the Western Screech-Owl differ in both size and color (Miller and Miller 1951, Marshall 1967). Because of the lack of specimens of M. k. cardonensis and xantusi in the collection at UABC, Unitt brought 10 specimens, including the holotype of cardonensis, from SDNHM to Ensenada for comparison. We quantified the color of the dorsal plumage with a Minolta CR-300 colorimeter. Because of the heterogeneity of the mottled plumage, we took 10 readings from each specimen measured and averaged them. We measured the specimens' wings in the standard way, unflattened, from the bend of the wrist to the tip of the longest primary. After analyzing variation in the screech-owls of the southwestern United States and northwestern Mexico on the basis of 438 specimens, Miller and Miller (1951) reported other external measurements to be uninformative.

Megascops $k$. bendirei (with quercinus as a synonym, Marshall 1967, Cannings et al. 2017), occurring in the northwest of Baja California, is considerably larger than the other subspecies of the Western Screech-Owl in the peninsula: wing length 162.5 \pm [standard deviation] $5.3 \mathrm{~mm}$ (Cannings et al. 2017). At a wing length of $145.6 \mathrm{~mm}$, UABC 2086 is much too small for bendirei, as well as differing in its finer plumage patterning. Marshall (1967) implied that the screech-owl population of San Diego County, Upper California, represents cardonensis, with which he synonymized M. $k$. clazus Oberholser, 1937 from a type locality still farther north in the San Jacinto Mountains, Riverside County. These conclusions do not account for the subspecies' wide difference in size, without overlap, as well as the difference in underpart pattern between the fine barring of cardonensis and the coarser barring of bendirei (Unitt 2004, Figure 3). Among 21 specimens of the Western Screech-Owl collected in San Diego County from 1979 through 2013 (SDNHM), the mean wing length of 10 males is $156.6 \pm 3.5 \mathrm{~mm}$ (range 151-160), of 11 females is $165.5 \pm 2.2 \mathrm{~mm}$ (range 162-169). The interpretation of Miller and Miller (1951), that the larger subspecies extends, along a cline of decreasing size, south to the Sierra San Pedro Mártir in Baja California is corroborated by two additional specimens from the west slope of that range, one from Rancho Santa Cruz $\left(30.875^{\circ} \mathrm{N}, 115.630^{\circ} \mathrm{W}, \mathrm{UABC} 474\right.$, male, wing chord $\left.153.5 \mathrm{~mm}\right)$, another from Rancho Mike's Sky (31.095 ${ }^{\circ} \mathrm{N}, 115.622^{\circ} \mathrm{W}$, UABC 2132, female, wing chord $166 \mathrm{~mm}$ ).

In the original description of M. k. cardonensis, Huey (1926) reported the wing length of four males to average $146.5 \mathrm{~mm}$ (range 144.5-148), of five females to average $149.5 \mathrm{~mm}$ (range 147.5-152). The measurements tabulated by Miller and 


\section{NOTES}

Miller (1951), based on the same specimens, do not differ materially. Thus at 145.6 mm UABC 2086 is typical of cardonensis in size. Cannings et al. (2017) did not designate measurements of cardonensis under that name, but because their entries for "M. $k$. xantusi" are essentially the same as those for cardonensis, and those for "M. k. xantusi (S. Baja California)" are on a separate line, we suspect the former are actually for cardonensis, just mislabeled.

Megascops k. xantusi of Baja California Sur is the smallest subspecies of the Western Screech-Owl with mean wing length of males $141.7 \pm 3.6 \mathrm{~mm}$ (Miller and Miller 1951). Thus UABC 2086 is within the range expected for xantusi, if on the large side. In pattern, however, it has the underparts finely barred as is characteristic of cardonensis, though more densely barred than in xantusi (Figure 4) or in the pale yumanensis of northeastern Baja California. In shade of the upperparts UABC 2086 is equivocal. The brightness of its dorsal plumage as measured by the colorimeter ( $L$, higher values represent paler color) was 32.8. In five specimens of cardonensis values of $L$ ranged from 28.2 to 32.7 , whereas in three of xantusi they ranged from 32.6 to 36.4 . Nevertheless, the dorsal surface appears to have the "salt and pepper" texture of fine dark freckles characteristic of cardonensis and bendirei (Figure 5).

We therefore extend the range of $M$. $k$. cardonensis south at least to $29.3^{\circ} \mathrm{N}$ and narrow the apparent distributional gap between the two peninsular subspecies. Additional specimens from between $27^{\circ}$ and $29^{\circ} \mathrm{N}$ would likely reveal intergradation between cardonensis and xantusi, as reported by Marshall (1967:13) on the basis of "the only available specimen from the middle of the peninsula," presumably the specimen from Campo Los Angeles.

We thank JiJi Foundation for financial support of the biological exploration of the Sierra La Asamblea. José Delgadillo for his valuable help in the identification of vegetation at our study site, Julián García-Walther for his help in the field, and Telésforo Sánchez and ranchers for helping us with horses and mules transporting equipment and people to the study sites. The Dirección General de Vida Silvestre of México permitted our collecting (09/K5-1652/05/16). Thanks to Kimball L. Garrett for sharing a photo of LACM 73852 and to Matthew J. Baumann and Daniel D. Gibson for their helpful reviews of the manuscript.

\section{LITERATURE CITED}

Bullock, S. H., Salazar-Ceseña, M., Rebman, J. P., and Riemann, H. 2008. Flora and vegetation of an isolated mountain range in the desert of Baja California. Southwest. Nat. 53:61-73; doi 10.1894/0038-4909(2008)53[61:FAVOAI] 2.0.CO;2.

Cannings, R. J., Angell, T., Pyle, P., and Patten, M. A. 2017. Western Screech-Owl (Megascops kennicottii), in The Birds of North America Online (P. G. Rodewald, ed.), no 597. Cornell Lab Ornithol., Ithaca, NY; doi 10.2173/bna.wesowl1.03.

Erickson, R. A., and Howell, S. N. G. (eds.). 2001. Birds of the Baja California Peninsula: Status, distribution, and taxonomy. Am. Birding Assoc. Monogr. Field Ornithol. 3.

Erickson, R. A., Carmona, R., Ruiz-Campos, G., Iliff, M. J., and Billings, M. J. 2013. Annotated checklist of the birds of Baja California and Baja California Sur, second edition. N. Am. Birds 66:582-613.

Howell, S. N. G., and Webb, S. 1995. A Guide to the Birds of Mexico and Northern Central America. Oxford Univ. Press, Oxford, England.

Huey, L. M. 1926. Notes from northwestern Baja California, with the description of an apparently new race of the Screech Owl. Auk 43:347-362; doi $10.2307 / 4075428$. 


\section{NOTES}

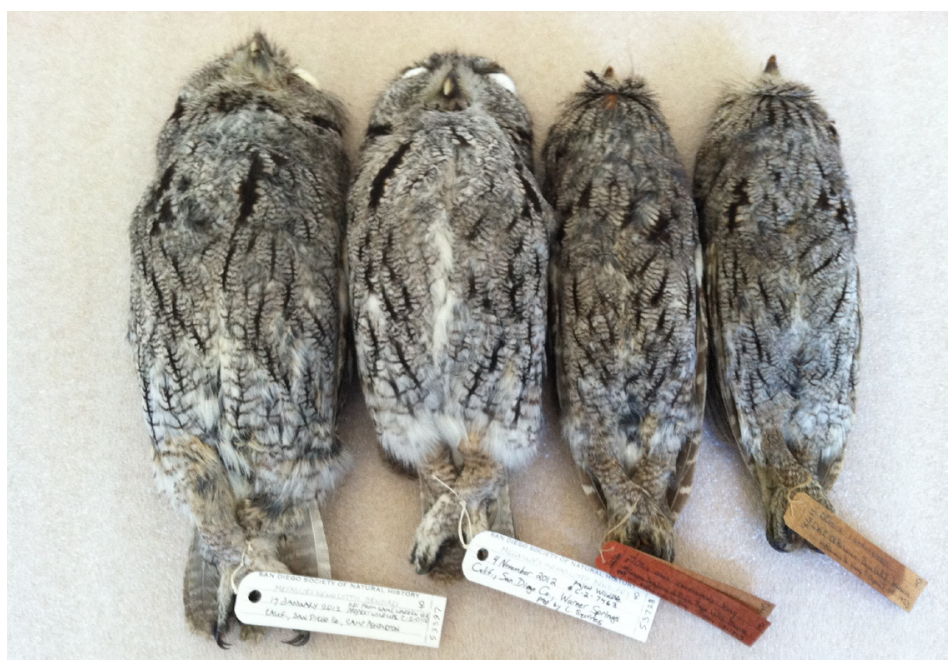

Figure 3. Pattern of underparts in Megascops kennicottii bendirei (left two specimens, SDNHM 53397 and 53728, both from San Diego County) and M. k. cardonensis (two right specimens, SDNHM 8671 and the type specimen, 8611). All specimens are females. Beside the wide difference in size, note the difference in pattern, especially on the belly: coarser in bendirei, finer in cardonensis.

Photo by Gorgonio Ruiz-Campos

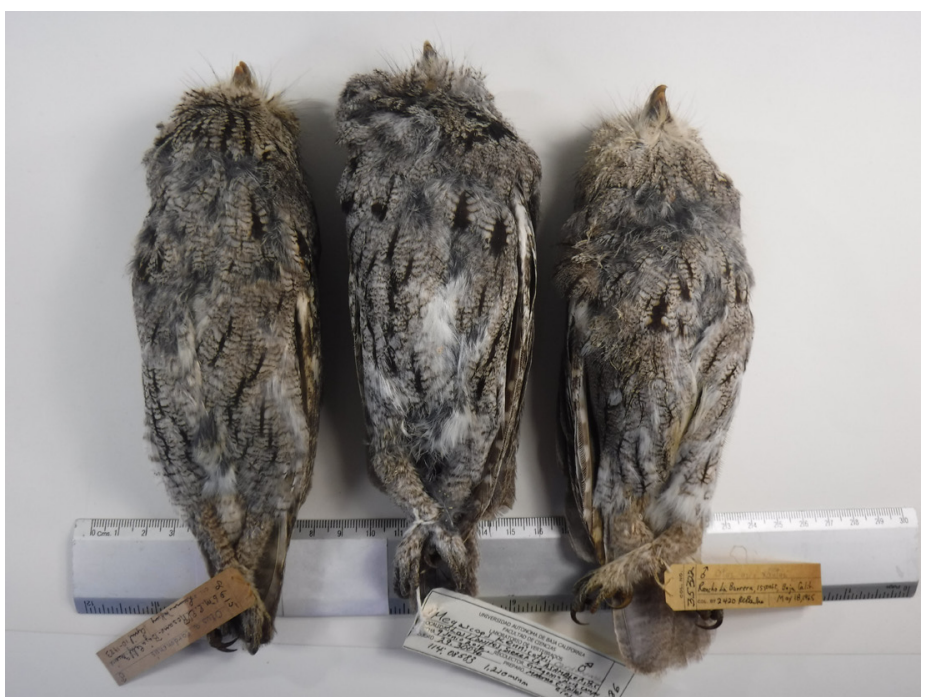

Figure 4. Pattern of underparts in Megascops kennicottii cardonensis (left, SDNHM 8615, center, UABC 2086) and M. k. xantusi (right, SDNHM 35322). 


\section{NOTES}

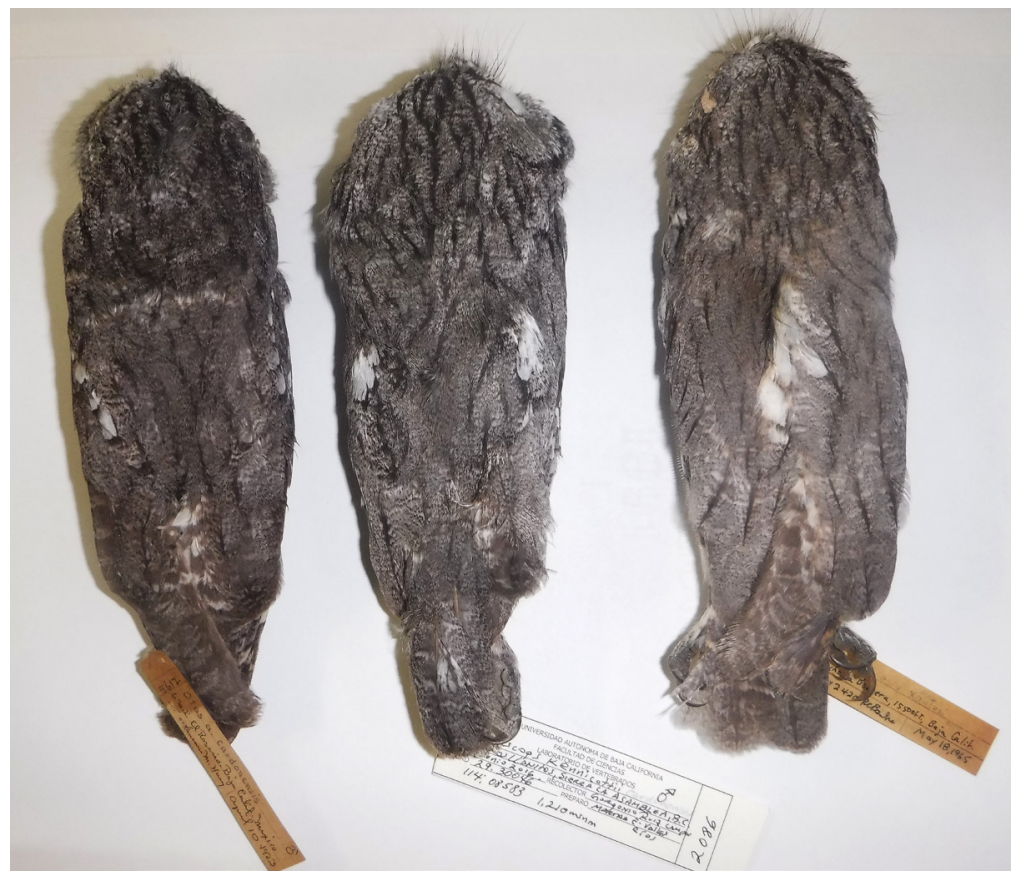

Figure 5. Pattern of upperparts in Megascops kennicottii cardonensis (left, SDNHM 8612; center, UABC 2086) and M. k. xantusi (right, SDNHM 35322).

Photo by Gorgonio Ruiz-Campos

Marshall, J. T. Jr. 1967. Parallel variation in North and Middle American screech-owls. W. Found. Vert. Zool. Monogr. 1:1-72.

Miller, A. H., and Miller, L. 1951. Geographic variation of the screech owls of the deserts of western North America. Condor 53:161-177; doi 10.2307/1364873.

Unitt, P. 2004. San Diego County bird atlas. Proc. San Diego Soc. Nat. Hist. 39.

Accepted 26 January 2018 